\title{
Ophthalmological Society of The UNITED Kingdom
}

Annual Congress, 1955

The Annual Congress will be held at the Royal Society of Medicine, 1, Wimpole Street, London, W.1., on April 28, 29, and 30, 1955. The presidential address will be delivered by Mr. O. Gayer Morgan on "Some Aspects of Thrombosis of the Retinal Veins and its Treatment". A discussion on "Sarcoidosis" will be opened by Dr. J. G. Scadding, Mr. A. G. Cross, and Mr. R. P. Crick. There will also be short symposia on "Diamox in the Treatment of Glaucoma", "Relaxant Drugs and Anaesthesia in Ophthalmic Surgery", and "The Use of Air in Ophthalmology".

The Bowman Lecture will be delivered by Dr. John H. Dunnington on "Ocular Wound Healing"'.

Members wishing to read papers, give demonstrations, or show films are asked to communicate with, Mr. Ainslie not later than December 31, 1954.

The Annual Dinner, to which members may bring guests, will be held on April 28. A Trade Exhibition will be held in the Cowdray Hall (next door to the Royal Society of Medicine). All members who will require hotel accommodation are advised to make their arrangements in good time.

$$
\text { Honorary Secretaries }\left\{\begin{array}{l}
\text { Arthur Lister (Council Business). } \\
\text { Derek Ainslie (Congress Business). }
\end{array}\right.
$$

\section{HoNOURS}

At a Convocation at McGill University, Montreal, on October 6, 1954, the honorary degree of Doctor of Science was conferred on Sir Stewart Duke-Elder.

Mr. B. W. Rycroft has been made an honorary member of the Ophthalmological Society of South Africa.

\section{OBITUARY}

\section{LeGrand H. HaRdy}

Dr. LeGrand H. HaRDY died on April 14, 1954, at the age of 59. He was a well-known and well-liked American ophthalmologist, Clinical Professor of Ophthalmology in the College of Physicians and Surgeons at Columbia University, and Director of the Knapp Memorial Physiological Optics Laboratories at the Presbyterian Hospital of New York. His main interest lay in the field of physiological optics in which he was recognized as a world authority.

\section{WALTER LÖHLEIN}

WE have heard with great regret of the recent death of Professor WALTER LöHLEN of Berlin, one of the foremost German ophthalmologists of his day, and until recently a member of the International Council of Ophthalmology. 